\title{
AN ASSESSMENT OF ROLE OF FAITH-BASED ORGANIZATIONS IN NIGERIA'S DEMOCRACY
}

\author{
EMMANUEL ADELEKAN OJEWUNMI \\ Email: revdojewunmi@gmail.com \\ Department of Politics and International Relations, Lead City University, Ibadan. Nigeria \\ DOI: $10.31364 / \mathrm{SCIRJ} / \mathrm{v} 8.17 .2020 . P 0720782$ \\ http://dx.doi.org/10.31364/SCIRJ/v8.i7.2020.P0720782
}

\begin{abstract}
This paper addresses the relationship that exists between democratic governance and faith-based organizations in Nigeria. The paper addresses to a certain extent, the relationship between the two main religions in Nigeria and democratic governance since 1999, with an analysis of the mutual impact one has had on the other, particularly how Christian and Islamic missions have influenced governance. The paper, using a historical method and instrument for data collection, analyses the various ways religious organizations have contributed to the stability of the democracy and identifies areas where they have failed to address the major problems confronting the country. It concludes that the faiths played a major role in the political construct and policymaking of some of the administrations.
\end{abstract}

Keywords: Christianity, Democracy, Governance, Islam.

\section{Introduction}

The major focus of this paper is to argue out the importance of faith-based organizations(FBOs) in democratic governance in Nigeria.

This paper also considers various scholarly perspectives on the concepts of governance and faith-based organizations concerning Nigeria's political activities. Furthermore, the paper also attempts to, investigates the relationship and competitive roles that exist between the two main religions in Nigeria namely Christianity and Islam, and how they have influenced the political activities in Nigeria.

In addition, the paper looks into the various roles that religious organizations have played in the past and how these have impacted the country both positively and negatively. It is on these bases that the paper gives its recommendations and admonishes the leadership of all the FBOs to reconsider their roles to influence politics of Nigeria and to use their privileges to improve the standard of living of their followers rather than to amass wealth at the expense of the common man in the country.

www.scirj.org

(C) 2020, Scientific Research Journal

http://dx.doi.org/10.31364/SCIRJ/v8.i7.2020.P0720782

This publication is licensed under Creative Commons Attribution CC BY. 


\section{Definition of Terms}

Governance: A publication by the World Bank defines governance as "the manner in which power is exercised in the management of a country's economic and social responsibilities for development" (World Bank, 1992). In addition to this definition, governance can be seen as an exercise of authority or control over a jurisdiction that one is presiding over. Governance in several contexts is used, such as corporate, international, national, and local governance. Good governance can be identified through these major characteristics: participatory, consensus, accountability, transparent, responsive, effective and efficient, inclusive, equitable, and above all it follows the rule of law (Chemimuya in Ayantayo, Dada, Labeodan 2012). The United Nations Development Programme Regional Project defines governance as "the role of the political system that solves conflicts between actors and adopts decision (legality). It also has been used to describe the proper" functioning of institutions and their acceptance by the public" (legitimacy). Furthermore, it has been to invoke the efficacy of government and the achievement of consensus by democratic means(participation) (Chemimuya in Ayantayo, Dada, Labeodan 2012). Thus, governance relates to the mechanism, structure, and process that guide political and socio-economic relationship of a country.(Noor, 2008)

Democracy: This was assumed to be the best governance by the powers who were victorious in 1918 . However, there was general agreement in 1919 that democracy required governments to be based on elections and that governments should be answerable to the people. (That is, people should be able to vote at regular elections to remove unpopular governments from power and to keep some control over what the government did with power (Watson, 1979) Democracy offers a stable form of government. Democracy is premised on upon majority rule or wishes of the citizenry and the principle of one man, one vote. In a democratic setting, a conscious and meticulous effort is made to see that the will of the majority prevails in the way and manner by which this leadership cadre is selected. It is this prevalence of the majority will, which distinguishes election from selection and by definition, democracy from every form of autocracy. Democracy must consciously go with the qualifications of being free and fair. Democracy cannot be said to exist where the elections are not conducted in free and fair elections (Mohammed. Edoh 1986) or in situations where the will of the people is not expressed in electoral proceedings.

On these premises, democratic governance can be described to be a system of government in which assumption of office is by majority elective decision or popular (majority) votes, it is a system that is accountable to the people and that has a specific tenure to be in power. It gives room for a periodic election to give room for achieving and enforcing accountability. In other words, accountability is the value component of democratic governance which decrees elections. There will be a caricature form of democracy if there is no room for accountability. That is, if accountability is not enforced, there cannot be a periodic election.

wWw.scirj.org

(C) 2020, Scientific Research Journal

http://dx.doi.org/10.31364/SCIRJ/v8.i7.2020.P0720782

This publication is licensed under Creative Commons Attribution CC BY. 
Faith-based Organizations: The concept of faith-based organizations (FBO) is: any organization that derives inspiration and guidance for its activities from the teachings and principles of the faith or a particular interpretation or school of thought within the faith. (Scoth, 2003) At a minimum, FBOs must be connected with an organized faith community either in the form of a particular faith ideology, drawing of staff, volunteers, or leadership from a particular faith denomination.(Clark, 2005) Other qualities that qualify an organization as "faith-based" are religiously oriented mission statements, the receipt of substantial support from a religious organization, or the initiation by a religious institution. (Afe, 2005) More importantly, it should be of note that FBOs are influenced in their advancement through the philosophies of their sponsoring religious organizations, denominations, or sects.

Furthermore, McCarthy and Castelli using geographical coverage and denominational independence were able to produce a 3 -fold typology of FBOs. They are as follows:

- Congregations: Locale specific community organized around religious worship

- National Networks: the social service components of major denominations

- Freestanding religious organizations- service organizations that are separate from any congregation or religious denomination. They have broad geographical scopes ranging from neighborhood-based emergency food and welfare agencies to large national organizations.(McCarthy, Castelli, 1999)

\section{Roles of Faith-based Organizations in Nigeria's Democratic Governance}

To start with, in a similar paper, titled "The Role of Faith-Based Organizations (FBOs) in Human Development: A Study of Kogi State", Baiyeri (2013) argues that Faith-based Organizations are seen to serve as religious instruments of social transformation in contemporary times. FBOs according to this paper's findings provide human development services such as educational, health and social services.

Another scholar in his book "Leadership, Good Governance and Democracy in Nigeria; Challenges and Prospects for Transformation" believe that as of today, religious politics between Christians and Muslims has emerged as the most critical and essential element of political life in Nigeria. (Odoh, 2011)

Furthermore, FBOs have also contributed in no small measure to the rapid increase in the number of voters in the country, especially during the 2019 general elections. Churches, Mosques, and other faith groups have helped in encouraging their members in registering for their Permanent Voter's Card (PVC), and in taking the pains for the collection of their PVC in local governments of their choice. This fact is, buttressed with the Nigerian Baptists that devoted her 2018 Convention theme for this purpose. The theme was "Moving WwW.scirj.org

(C) 2020, Scientific Research Journal

http://dx.doi.org/10.31364/SCIRJ/v8.i7.2020.P0720782

This publication is licensed under Creative Commons Attribution CC BY. 
Forward: Building a Great Nation Through Effective Christian Participation”. Furthermore, one of the Baptist ministers Rev. Adeyeye Oyedokun in one of his teachings on politics, titled "The Disciple and Political Issues" says "The slogan these days is that "your vote counts'. However, before your vote can count, (he added), you must have registered and obtained a voter's card.” (Oyedokun, 2018). In addition, a retired judge, Justice A.A. Kolajo also lends support to this argument when he said during one of his teachings on "Being a Good Citizen" that "A good citizen is expected to participate in electoral processes. Voting gives citizens, the opportunity to contribute to good governance". (Kolajo, 2017) These buttress the fact that religious leaders, especially in the last concluded general election, helped the government to disseminate the information to their members on the importance of PVC, which is the only power to have the choice to vote in their chosen candidate. In the researcher's interaction with some clergies, many of them emphasized the fact that they all involved in giving admonition to their followers on the need to participate in the general elections through registration for PVC and exercising their franchise rights during elections in the country.

In addition to these, the FBOs have also encouraged their members to go and vote on the various election dates. Many Christian preachers and Islamic clerics have used their various messages to inform, educate, encourage, and instruct their members of their faith to participate in the electoral process that is, to vote. During 2019 Nigerian general election period, there was a slogan that the Nigerian Baptist Convention leadership adopted during the 2018 annual convention at Port Harcourt that read "to vote a credible candidate is not based only on prayer but to go out to vote" to serve as an encouragement to the participants to exercise their franchise rights on election dates.

The increase in participation of Christians in politics has helped greatly in fostering cooperation in Christian-Muslim relations, particularly those of the same political parties. This trend has helped several parties, especially where the two faiths have an almost equal representation develop a political ideology of "Christian-Muslim and Muslim-Christian choice/ticket technique" as seen in many states of Nigeria for example in Oyo, Ogun, Lagos, Nassarawa, Kogi and at the Presidency. To buttress this point. President Mohammadu Buhari picked Prof. Pastor Yemi Osinbajo who is a Christian as his running mate purposely to win the votes of the Christian faithfuls. Similarly, in Nasarawa State, the current governor who is a Muslim picked a Christian as his deputy to garner the vote of the Christian fold because the State is not predominantly Muslim. Likewise, in Oyo State where the former governor was a Muslim who had a Christian deputy, while the current governor, Engr. Seyi Abiodun, Makinde, a Christian has a Muslim deputy in the person of Engr. Rauf Olaniyan. Furthermore, such development also happened in almost all the States that are religiously diversified examples of such States include Kogi, Ogun, Osun, Niger, and many others. The fact of the matter is that this choice of a team contestants from the two leading religions is somewhat becoming an effective tool to reduce the emphasis on religious sentiments as a condition to the choice of a particular candidate or political party to join and vote for during general elections.

WWW.scirj.org

(C) 2020, Scientific Research Journal

http://dx.doi.org/10.31364/SCIRJ/v8.i7.2020.P0720782

This publication is licensed under Creative Commons Attribution CC BY. 
In addition, FBOs have also helped largely in sustaining this democratic governance through constant challenges given to the elected political office holders in their weekly and special occasions like funerals, birthdays, weddings and so on. The clerics have been found using such gatherings to challenge the officeholders to be of good moral standing to shun all forms of fraudulent activities and to be of good ambassadors of the people in the offices they serve.

Moreover, several public criticisms of government policies by the religious umbrella bodies such as the Christian Association of Nigeria (CAN), Catholic Bishops' Conference of Nigeria (CBCN), Nigeria Supreme Council for Islamic Affairs (NSCIA) and many others have been great checks on governments at all levels in Nigeria. The criticisms have helped in re-shaping government decisions and the implementation of such decisions. It has reduced government sentiments religious biases, and immoralities because religious bodies are good watchdogs on government activities and their behaviour on society.

Meanwhile, the government's decision to create inter-religious bodies such as the Council for Religions for Peace co-chaired by the Chairman of the Christian Association of Nigeria and the Sultan of Sokoto, the chairperson of Nigeria Supreme Council for Islamic Affairs is a move in the right way. This council has helped avert several religious crises that would have occurred in the country. This inter-faith council has also helped in educating its numerous members on political matters and to disseminate governmental policies to the general populace which has also eventually reduce the people's ignorance on political matters. It has also helped people to demand their civil rights and responsibilities from the Nigerian State.

FBOs in Nigeria have begun to develop more interests in the anti-corruption crusade to reduce the level of corruption in the country. An instance, was in February 2017, during the flag-off of the Women against Corruption campaign in the South-West, the wife of the General Overseer of the Redeemed Christian Church of God (RCCG), Pastor Mrs. Folu Adeboye said,

"Let us drive the anti-corruption campaign in our homes; let us put things right; change whatever needs to the changed, and correct whatever needs to be corrected to ensure that corruption is no longer plaguing the Nigerian society and that Nigeria reaches its Godordained destiny." (The Daily Trust, February $23^{\text {rd }}, 2017$ )

Likewise, an Islamic scholar Yusuf Ali San also lends his support to this argument when he says "If corruption is to be given short shrift in Nigeria, then the social, business and bureaucratic environments must be corruption-hostile rather than friendly." (Yusuf, 2016) Corruption, which is the bane of development in Nigeria and Africa, in general, has resulted in other heinous vices that have ravaged the society. Misappropriation of funds, extortion, bribery, the spirit of domination in politics, injustice, nepotism, and the imposition of leadership have great consequences on the people of Nigeria and the major cause is corruption which has eaten deep into the state treasury. FBOs in Nigeria have been found in recent times to frown on this through their criticisms and messages which

WwW.scirj.org

(C) 2020, Scientific Research Journal

http://dx.doi.org/10.31364/SCIRJ/v8.i7.2020.P0720782

This publication is licensed under Creative Commons Attribution CC BY. 
are means of changing the trend. Religious leaders are not exempted from this criticism as Bishop Matthew Hassan Kukah says that the clergy are allowing politics "to corrupt the sacred spaces of worship”. He continues by saying "Thus we have lost our voices and no longer seem to have the capacity to interrogate power as we are called to do" (The Crux: $3^{\text {rd }}$ April, 2018).

Similarly, the interplay of religion and politics in Nigeria among the FBOs in Nigeria has assumed a new trend. The high level of Muslim participation in government has forced both the Christian Association of Nigeria (CAN) and the Pentecostal Fellowship of Nigeria (PFN) to be more proactive in political debates in contemporary Nigeria (Lahore, 2009), Muslims in power often use power politics to sidetrack Christians on issues of national character. This interplay has generally improved the political consciousness of the citizenry which now makes it more competitive, interesting and to improve the quality of politics being done in Nigeria. In addition, each has become a watchdog of the other in the country (Lahore, 2009.)

\section{The Role of FBOs in Democratic Governance in Nigeria}

Essentially, both religion and politics have one goal: that is, acquire power and use it to realize their goals. However, to achieve this objective, their methods are different. Religion mobilizes religious sensibilities of the people to get their support to capture religious power, while politics uses intrigue, diplomacy and makes attempts to win public opinion either democratically if the system allows it or with the help of an army if the system is under-developed and backward (Lahore, 2009) To this extent, this usually causes a power struggle in which both religion and politics try to undermine each other. If religion holds political authority, its ambition is to use it to fulfill a divine mission. It claims that it derives authority from divinity and therefore, its mission is holy, motivated to reform society under spiritual guidance. Politics on the other hand, bereft of any value, direct its policy on the needs and requirements of society whereupon it obliges to change laws and system of government accordingly as explained by Fr. Francis Omonokhua in the Daily Trust on Friday, (18 ${ }^{\text {th }}$ December, 2018). From these, three models can be gleaned:

- In one when religion and politics both unite in an attempt to monopolize political power. This is what is known as the integration and sharing model.

- In the $2^{\text {nd }}$ model, politics, after subduing and overpowering religion, uses it for its interest. In this model, religion is subservient.

- In the third model, both come into conflict with each other that subsequently lead to their separation. In this model, they appear as rivals and compete to struggle for domination. (Lahore, 2009)

This relationship whichever amongst the models when it presents itself always favours the rich. The common person is never favoured because each party is always after its interests and not in the interest of the ruled class (workers, peasants).

WwW.scirj.org

(C) 2020, Scientific Research Journal

http://dx.doi.org/10.31364/SCIRJ/v8.i7.2020.P0720782

This publication is licensed under Creative Commons Attribution CC BY. 
The religious and secular leaders expected to lead in sound morality, obedience to the laws of God and the state constitutions are now after their selfish ambitions. They are not demonstrating good leadership to the people. This has greatly reduced the people's trust and interest in their leadership. The leaders in all sectors of the country and religious groups are no more seeking God's kingdom, holiness, righteousness, and godliness. It is very hard to find saints among them because corruption, which they preach against, is a cankerworm, which has eaten deep into their lives and systems of leadership. Some politicians, after leaving offices are found to enrich themselves illegally and the religious leaders are not exempted as they move around in flamboyant clothes, costly cars, jets, elegant mansions, etc. at the expense of their followers. This has reduced people's trust and belief in the leadership of the country.

The leaders in the FBOs as at present have no moral courage to preach morality, sound doctrine, eternal life, etc. because their mission is to change the hearts and minds of people by words and actions. They must be models in transforming the lives of people by ensuring that the politics within their circle and denominations are done in an ideal manner and is also worthy of emulation by the secular world. But the experience is different from this. That is why the voice of FBOs is not strong enough like the old prophets to correct the ills of Nigerian society. The FBOs, of today, lack the model through godly governance to have the moral courage to preach against the sins that are putting the citizens in pains and penury. Meanwhile, political parties (especially in Nigeria) cannot be the savior of any nation as long as inter-party differences promote hatred between brothers and sisters, people of different religious backgrounds, ethnicity, and languages. The question one may ask is how the FBOs can serve as watchdogs to the political leaders when the same sickness that worries the government is taking its toll on the FBOs, which are supposed to proffer a cure for the sickly nation of Nigeria.

In addition, FBOs have been playing the role of aiding and abetting the corrupt political leaders, because several cases of corrupt leaders bringing the parts of the stolen funds to their various places of worship without being condemned but rather being lauded and praised to the surprise of the citizenry of Nigeria. All these are problems for the nation's democratic governance.

The religious crises in Nigeria are another pointer to the failure of religious bodies and the politicians in fostering peace within the country. There are two types of religious conflicts in Nigeria, these are intra- and inter-religious religious conflicts. Intra religious conflicts often exist within a particular sect or denomination. Examples are the Maitatsine riot of 1980 in Kano and the skirmishes between the Izala and the Tijjanyya in Gombe in 1987. Inter-religious conflicts are conflicts between two or more different religious groups or traditions. Examples are the ABU students' religious crises of 1986,1987, and 1988 which led to the closure of all tertiary institutions in 1988. Another recent example is the crises that occurred in Southern Zaria of Kaduna, which led to the death of several adherents. Also is the murder of a female member of the Redeemed Church of God in Abuja who was preaching early in the morning and a gruesome killing of a female member of the Deeper Life Bible Church in 2018 by some men in Kano City simply because she

$$
\text { WWW.scirj.org }
$$


was eating publicly during the Ramadan period. All these were caused as a result of bad religious and political leadership. To cap it all on November 22, 2002, there was a protest against the "Miss world Beauty Contest" scheduled to hold later on December 7, 2002, in Abuja (Miss Hope, 2003).

Finally, because of their persistent efforts to retain power for long, the politicians have seen FBOs as an avenue to avoid criticism and also gain popularity. They keep on dishing out various funds and benefits to their spiritual leadership to gather their support and amass votes during elections. Likewise, the FBOs see the government as a means to actualize their dreams, visions, and plans for their groups. Therefore, they withhold criticism when necessary. They become sycophants who sing the praises of these politicians to win their favour. All these affect the democratic governance of Nigeria. Nigeria as a whole would be better off if both parties play according to the rules of the game. The religious leaders must see themselves as accountable and responsible to God, and as such must play the game according to divine rules, whereas politicians must see themselves as accountable to the electorates and must play the game in accordance with the constitution of Nigeria without sentiment, bias and personal interest.

\section{CONCLUSION}

Evidence has shown that Nigeria is highly blessed with several human and mineral resources even more than some leading countries. Nigeria's underdeveloped state is a result of the selfish ambitions and actions of the FBOs and the political leaders. Since independence, Nigeria has been suffering from bad leadership with people that have no vision and are non-enterprising. The religious leaders have not displayed a sincere spiritual quality that will spur the people into positive change. The spiritual leaders have a larger role to play in checkmating the politicians. Serious and morally upright people are expected to begin to actively participate in Nigerian politics. The FBOs should begin to teach their members to sound doctrines and they should also abide by their teachings.

Secondly, the citizens should stop encouraging stealing from government coffers by giving those found guilty of this a rousing welcome. An example is the case of Chief James Ibori (former governor of Delta State) who was greeted with pomp and pageantry upon his release from prison in the United Kingdom. This served as an encouragement to stealing and still be involved in fraudulent activities. In addition to this, the immediate past minister for communication Barr. Adebayo Shittu (a Muslim) was left untouched despite his failure to serve in the National Youth Service Corps, he was left to finish his ministerial appointment whereas, the pressure was mounted on Mrs. Kemi Adeosun (a Christian) the former minister for finance in the same cabinet with Shittu in Mohammadu Buhari first term of 2015-2019. She was forced to resign her ministerial appointment by her political opponents within the same political ruling party. This is unfair to the democratic governance of Nigeria. For governance to be sustained there should be no partiality, sentiment, and different measurements to judge the situation. People must be treated equally. The voters should be

www.scirj.org

(C) 2020, Scientific Research Journal

http://dx.doi.org/10.31364/SCIRJ/v8.i7.2020.P0720782

This publication is licensed under Creative Commons Attribution CC BY. 
encouraged to express their views, as was the case of Omoyele Sowore who was held by DSS for criticizing the government of President Mouhamadu Buhari in 2019.

Finally, the political class should allow fairness and justice to prevail in state matters. There should be accountability on the part of all leaders to repay the trust of the populace. But all concerned should note that accountability can only be demonstrated in democratic governance by leaders whose lives are full of a high sense of accountability to God, those who act with the fear of God and are ready to lead sacrificial lives. If these conditions are met, then Nigeria will be better off in this generation and for many generations to come.

\section{Recommendations}

For the Nigerian state to have a better quality of democratic governance, participation of members in these FBOs who are spiritually and morally upright in politics must be encouraged. Constant prayers and supplication for the nation for good and sustainable governance need to be intensified.

Similarly, seminars, workshops, and conferences need be put in place by religious bodies to sensitize the members especially those with political capabilities to join political parties for active participation in politics and all members in general to always exercise their civic rights during general elections. Also, the leadership of these FBOs should desist from calling politics "a dirty game for dirty people" because to leave politics in the hands of these "dirty people" is equivalent to allowing a blind man to drive one's car with the entire family inside, every passenger of that car would perish. If only the vagabonds, illiterates, ungodly, and corrupt are allowed to lead the nation, things would go from bad to worse. Religious people are supposed to be light in their society in words and deed. So, if good religious people who are expected to lead the country are hiding in fear of "contamination" then what purpose do they serve for their society?

Apart from the sensitization of members, the FBOs also need to give more support to the democratic governance in Nigeria. On the Pastor's pulpit and in the Mosques, emphasis should be laid on voters' registration exercise as the civic duty of every Christian, Muslim, and traditional worshippers. They should also warn them against the implication of selling their votes to fraudulent politicians. They should warn them of the problems and implications of engaging in thuggery or any form of electoral vices. They should let them know that offenses against the state are against their particular faiths and God.

Meanwhile, the FBOs are not out of place if they fathom out punishments against all forms of electoral misconduct and offenses committed by their members engaged in political activities of the country. In general, the requirement for better and accountable governance to the populace is a radical change in the attitude of the electorate and political officeholders. The country needs trust-

WwW.scirj.org

(C) 2020, Scientific Research Journal

http://dx.doi.org/10.31364/SCIRJ/v8.i7.2020.P0720782

This publication is licensed under Creative Commons Attribution CC BY. 
worthy men and women who have proven character from FBOs to take up the mantle of leadership and lead the country to the promised land.

Finally, the leadership of the FBOs and the politicians are the books the people are reading every day. Therefore, they are to lead by example. The spiritual leaders are urgently needed to focus on eternal matters. They should seek the kingdom of God first, lead a moderate pattern of living and avoid the excessive pursuit of wealth and other material things to avoid misleading their followers. Likewise, the political class should bear in mind that they were also called to lead the people rightly. They should be accountable to their electorates and judiciously use the state resources for the benefit of all members of their communities. Above all, each of them should remember that a day would surely come when each of them will stand before the throne of almighty God to give an account of their stewardship. Therefore, it is expected of every leader to be found trustworthy in the areas of their calling. They should use their privileges of office to improve the welfare of all and sundry and not just for the pursuit of their selfish ambitions, because to this they were called by divine approval.

\section{References}

1. “God will Soon Pass Judgement on Corruption in Nigerians- Pastor Adeboye's wife 'Prophesies'” in The Daily Post February, $23^{\text {rd }} 2017$ by Danielle Ogbeche.

2. “On Easter, Nigerian Bishop rebukes religious leaders over corruption” in Crux: Taking the Catholic Pulse. April 3 rd, 2018 by Ngala Killian Chimtom

3. "The Challenges of Fighting Corruption in Nigeria: Islamic Perspectives. Lecture delivered by Yusuf Ali San at Ogun State Judiciary 2016/2017 Muslim Legal Year Service on $26^{\text {th }}$ September 2016 at Egba Central Mosque, Kobiti, Abeokuta, Ogun State.

4. Afe A. 2005. "Politicization of Religion and Religionization of Politics in Nigeria, in C.J Koreh and Politics in Nigeria" (essays in honour of Ogbu. U.Kalu.) New York: University of America.p129-130.

5. Baiyeri, H. "The Role of Faith-Based Organizations (FBOs) in Human Development: A study of Kogi state”. Presented at the Department of Religion and Cultural Studies: Faculty of Social Sciences, University of Nigeria, Nssukka. Retrieved May 10, 2019.

6. Chemimuya, C. C. Religious Ethics, and Governance in Ayantayo J.K, Dada O.A \& Labeodan H.A, (ed) 2012: Religion and Governance in Nigeria. U.I Department of religious studies. Series, Volume 4. P. 228

7. Clark G. 2005 “Faith Matters: Development and complex world of faith-based organizations”, paper presented at the annual conference of the development studies Associations. Milton Keynes, Open University, 7-9 September, Pg 4

$$
\text { WwW.scirj.org }
$$

(C) 2020, Scientific Research Journal

http://dx.doi.org/10.31364/SCIRJ/v8.i7.2020.P0720782

This publication is licensed under Creative Commons Attribution CC BY. 
8. Fr. 'Omonokhua, C. “Religion and Politics in Nigeria”. Daily Trust, Friday, December 14, 2018.

9. Kolajo, A.A. 2017 “Being a Good Citizen”. Disciple’s lifestyle for Churches, Small Groups, and Schools. Ibadan. Baptist Press, Pg 197.

10. Lahore, A. M. 2009. Religion and Politics: Integration, Separation, and Conflict. Modops Blog.

11. McCarthy J. Castelli, J. 1999. "Religion Sponsored Social Service from the Not So Independent Sector”. Washington DC Non-profit Sector Research fund. The Aspen Institute Working Paper Series.

12. Noor A. 2008. Ethics, religion, and Good Governance, Joaag. Vol. 3. No. 2. http://joaag.com /uploads/6-Noorfind. 3.2. pd8. Retrieved on $27 / 10 / 2010$

13. Odoh, P. "Leadership 2011. Good Governance and Democracy in Nigeria: Challenges and Prospects for Transformation". Husis Digital Press. Nassarawa Road, Kaduna. Pg 39.

14. Oyedokun, A. 2018 “The Disciple and Political Issues” in Disciple's lifestyle for Churches, Small Groups and Schools. Ibadan. Baptist Press, Pg 166.

15. Scoth. J. D 2003 "The Roundtable on Religion and Social Welfare Policy: The scope and Scale of Faith-Based Social Services" Rockefeller Institute of Government/ Few Trusts

16. Siddique, A. \& Edoh T. (ed) 1986 “Nigeria: A Republic in Ruins” Zaria: Gaskiya Corporation Limited.P. 3

17. Watson, J. 1979 "Success in Twentieth-Century World Affairs". London Fletcher and son LTD.

18. World Bank (1992) Report- Managing Development- The Governance Dimension, Washington DC, USA.

19. Lahore B. 2009. "Islamic Renewal Radio and the surface of things. In B. Meyer (ed), Aesthetic Formations: Media Religion and the Senses" (New York: Palgrave Macmillan) $12 \mathrm{~b}$.

20. The Hope, "Miss World at Alexandria Palace" (Nov. $27^{\text {th }}-3^{\text {rd }}$ December 2002).

www.scirj.org

(C) 2020, Scientific Research Journal

http://dx.doi.org/10.31364/SCIRJ/v8.i7.2020.P0720782

This publication is licensed under Creative Commons Attribution CC BY. 